\title{
Overview of Deming Criteria for Total Quality Management Conceptual Framework Design in Education Services
}

\author{
Nursuhana Alauddin and Shu Yamada \\ Graduate School of Science and Technology, Keio University, \\ 3-14-1, Hiyoshi, Kouhoku-ku, Yokohama-shi, Kanagawa-ken, 223-8522, Japan.
}

\begin{abstract}
Nowadays, education institutions obtain more significant influence based on society needs compared to previous years. The rise of demands towards the quality improvements in education services and awareness in being more competitive to fulfill customers' requirements has paved a way towards better quality management. One of the quality improvement models that could be implemented is Total Quality Management (TQM), which has been widely used in industries and service sectors. In order to ensure the success of TQM implementation, there are various awards to recognize the quality initiatives by the organizations, and one of them is known as the Deming Prize. In this paper, the Deming criteria from Deming Prize award is overviewed to design a new TQM conceptual framework for education services to improve the total organization system. It complements three main principles; i) the establishment of business objectives and strategies, ii) the suitable utilization and implementation of TQM, and iii) the effects and impacts of TQM. In the next stage, a conceptual framework will be designed and used at an educational institution for the TQM system implementation. It is expected that this study will lead to new insights on TQM implementation in education services.
\end{abstract}

\section{Keywords: TQM, Deming Prize, Deming 14 Points, PDCA Cycle}

\section{INTRODUCTION}

Total Quality Management (TQM) is a philosophy for management to empower the entire organization and encourage each individual to contribute and participate in organization improvement and betterment. The word of TQM, which consists of "total", "quality", and "management", is interpreted widely by various authors and researchers. TQM has been widely and successfully used in manufacturing industries for decades. The service sector practitioners, including in education services, have started to explore the possibility and potential of TQM practice in their industries. Nevertheless, there are difficulties in mapping the education service elements with manufacturing industry elements, such as customers, outputs, and workflow, which may give influence to TQM implementation.

Although it is complicated to adopt TQM in education service, the awareness to improve the educational processes and the concern in providing a better quality of services has increased from time to time. Recently, studies of TQM implementation in education has been started in several countries, and positive impact through the application were experience by the institutions. In this paper, the Deming criteria are overviewed and mapped to education to create a comprehensive and useful TQM model specifically for education services.

\section{LITERATURE REVIEW}

\section{Quality and TQM}

From the quality management evolution history, TQM has emerged in industries over a long period. Some authors identified it as the four stages of evolution, and others proposed that TQM evolved through three different periods [1]. The four major development eras since the last two decades can be identified as quality inspection, quality control, quality assurance, and total quality management [2]. W.

Corresponding Author: Nursuhana Alauddin, Graduate School of Science and Technology, Keio University, 3-14-1, Hiyoshi, Kouhoku-ku, Yokohama-shi, Kanagawa-ken, Japan 
Edwards Deming, Joseph M. Juran, Armand V. Feigenbaum and Philip Crosby are the big names who have majorly contributed and played essential roles in shaping the quality management, especially the TQM as of today.

The word "quality" itself can be defined in different perspectives and dimensions as it is a relative concept by different people. Deming [3] emphasized that quality is all about people and not products. The satisfaction of the customers defines quality, and since the customers' needs and expectations are always changing, the organization has to adapt and respond to those changes. The ideology of Deming 14 Points is to improve the effectiveness of an organization or a business significantly. Juran interpreted quality in two meaning; the features of products which meet customer needs, thereby provide customer satisfaction and the freedom from deficiencies. Quality may be defined as fitness for use, and it only can be assessed on a deep understanding of the particular customers and their needs. Moreover, the process of managing quality makes extensive use of the three managerial procedures; quality planning, quality improvement, and quality control, also known as the Juran Trilogy [4].

Feigenbaum [5] highlighted that the total quality control is an effective system for integrating the quality development, quality maintenance and quality improvement efforts by various groups of people in one organization to fulfill the customer satisfaction. On the other hand, Crosby [6] defined quality as conformance to the requirement to improve quality and eliminate hassle at the same time. The "do it right from the first time," or DIRFT is when the requirements are clearly understood and not putting things in people's way. Also, he created a Zero Defects concept in 1961, which relates to the DIRFT idea.

JUSE [7] expressed quality as the degree to indicate whether it is good or bad overall, by gathering the various requirements of such evaluators. As in Japan, the quality word itself has two interpretations based on the different industries; in the manufacturing industry and service sector as the term "quality" is defined with “product quality (品質)” and “quality (質)”. However, after all, it is all set as the word "quality" in English [8]. It is interesting as the involvement of the product to be delivered to customers is categorized as tangible or intangible. Based on ISO 9000 in clause 3.7.7, the service organization such as the educational bodies that deliver knowledge and information transmission, is categorized under the service sector, which provides intangible products to customers [9].

JUSE interprets TQM as a collection of ideas, initiatives, methods, mechanisms, and methodologies for maintaining and improving overall "quality" in corporate activities. These efforts will then shape corporate events toward the achievement of management goals [7]. TQM implementation has been adopted with its roots in manufacturing [10], later on, spread into services and healthcare [11], and recently has been penetrated in government and education sectors [12]. Since the TQM concept was initially developed for the manufacturing industry, therefore, there is a great deal of concern whether this philosophy is applicable in education or not. The organizations related to education might have a hard time implementing TQM in their services as of its nature, and the process of delivery is not similar to the industrial area. In [13], the significant difference between school and manufacturing company in term of processes involved in each sector was presented, especially the engagement with the customers. It shows how complicated the education process is to implement TQM if the philosophy behind it is not well-defined.

TQM is defined as a set of systematic activities carried out by the entire organization to effectively and efficiently achieve the organization's objectives to provide the products and services with a level of quality that satisfies customers, at the appropriate time and price. Through this definition, seven important phrases need to be focused, and the Deming Prize committee describes further explanations in the Deming Prize application guidelines [14]. TQM has the basic viewpoints of "customer orientation", "respect for humanity", and "profitability". Based on this perspective, various efforts in increasing the motivation and awareness of the entire company will be carried out.

Nevertheless, a plethora of studies for TQM implementation in education services, especially in higher education institutions, were being conducted in several countries. Some authors implemented TQM as a tool to improve the quality of primary education system, including the improvement of classroom environment quality through $5 \mathrm{~S}$ in motivating students to go to school [15]. In [16], the TQM core elements such as leadership, strategic planning, and focus of customer satisfaction, that can be used as selfassessment practice in higher education institutions 
was highlighted. Besides, [17] emphasized that there are nine steps of TQM model for higher education institutions. Through the steps, after obtaining the top management commitment to determine the mission and vision statement in stage 2 , the customer definition is determined through customer surveys or customer needs in step 3.

Unfortunately, most of the literature focused on the implementation of TQM with various tools and processes to improve education system through TQM core values without further explaining on how to achieve the mission and objectives of the school or education institution. Quoted the general TQM definition by the Deming Prize committee, the main idea of TQM implementation in the education context is to achieve school objectives and strategy by the supports of TQM processes or tools. Besides, the customer definition shall be considered during the formulation of school objective and strategy, which means the school objective and strategy must be customer-oriented.

To ensure the TQM implementation is successful and provides positive impacts to the business objectives, the quality award is introduced. There are various awards from different countries and regions such as the Deming Prize, Malcolm Baldrige National Quality Award (MBNQA), and the European Foundation for Quality Management's Excellence (EFQM) award. These awards are being used by the organizations in both the private and public sectors to conduct self-assessments to measure their improvement progress and company potential [18]. In this paper, the framework is proposed from the perspective of TQM implementation by the understanding of the Deming criteria in Deming Prize.

\section{Deming Criteria in Deming Prize}

Deming Prize is one of the highest TQM awards in the world. It is established in 1951 in the commemoration of the late W. Edwards Deming, who majorly contributed to Japan's proliferation of statistical quality control after World War II. He helped Japan in building its foundation by which the level of Japan's product quality has been recognized as one of the highest globally. Based on statistic available at JUSE website, as in 2018, there are 252 organizations, including 55 oversea companies, has won the Deming Prize award. Among all, $98 \%$ of the winners are the manufacturers in Japan and other countries; only five of them are from service sectors and none from education service [19]. As such, it is worth to benchmark the success of the manufacturing and service sectors who have won this award to create excellent education services.

Compared to other quality awards, the Deming Prize has a unique way of assessment and evaluation process. Koura mentioned that the MBNQA and EFQM are used as self-assessment evaluation for companies that pursuing business excellence. On the other hand, for the Deming Prize, it is focusing on the concept of TQM at the operation site [20]. Izadi et al. stated that the Deming Prize application process is challenging. It usually takes three to five years for the managers to convince the Deming Prize committee to conduct the assessment and examination at the company site. The examination process is carried out by the experts of TQM, and they will audit the quality system carried out in the applicant's company [21].

The Deming Prize Committee views the process of examination as an opportunity for "mutualdevelopment," rather than "examination." They do not specify what issues need to be addressed, but the applicants themselves are responsible for identifying such problems. Thus, this process allows quality methodologies to be further developed by the companies, which helps to strengthen their capabilities. The applicants could use the Deming criteria as the guidelines, and they should embrace TQM as the management philosophy to be more successful.

\section{Philosophy of Deming 14 Points and PDCA Cycle}

Deming 14 Points, as shown in Fig. 1, is vital in aiming to make people work with joy. Stressing the role of management in leading the comprehensive and continues improvement of the system and the continuous development of people. It can be applied anywhere, to small organizations as well as to large ones, to the service industry as well as to manufacturing. Perhaps, the Deming philosophy is the key feature of the Deming Prize. The method promotes self-discovery in a company to embed the continuous improvement processes and ensure the organization's survival even if there is a change of leadership [18].

Several authors were using Deming 14 points to deploy the understandings to be used at school levels and higher education institutions. Lunenburg suggested that Deming 14 points could be used as a basis for achieving excellence in schools [22]. Hughey further explained how each of the 14 points is useful to make more exceptional quality, accountability, and fulfill 
customer satisfaction in higher education [23]. Farooq et al. [24] agreed that focusing on TQM is the fundamental way of fulfilling the accountability to reform the education, especially the no-fear TQM system in Deming 14 points. Each point in Deming 14 points would have its interpretation and perspectives in education services based on cases and context. The example of TQM practice in secondary school from Deming principles is explained in [25], and it utilized the exploratory research design approach for measurement based on a conceptual framework. All the above authors have elaborated every single point differently depending on knowledge, kinds of literature, and experiences.

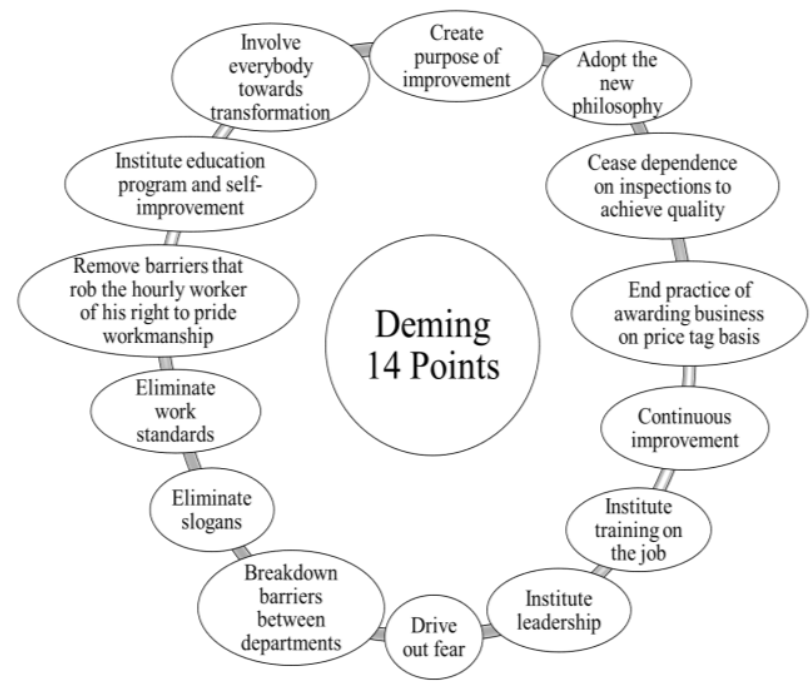

Fig. 1: Graphical image of Deming 14 Points

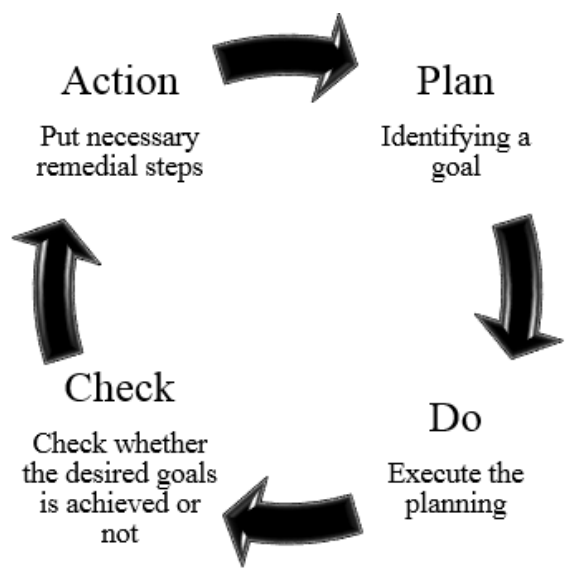

Fig. 2: Graphical image of PDCA Cycle
Another important philosophy is PDCA Cycle or known as the Deming Cycle, and it emerges in the Deming criteria application process. As shown in Fig.2, the Plan-Do-Check-Action is a systematic way of managing quality and provides steps for obtaining knowledge and essential learning for the continuous improvement of product development or process. It starts by identifying a goal or finding a problem, formulating the theory, and planning it into actions (Plan). The next step is to execute the planning and implement it as decided before (Do). After that, to continue the evaluation of whether the desired goals have been achieved or not (Check), and then determine what the necessary remedial steps are to achieve their goals (Action). These are the four steps that will be repeated all over again as part of a continuous improvement in every process [26]. The relationship between Fig. 1 and Fig. 2 with the Deming criteria is elaborated in the next section.

\section{MAPPING OF DEMING CRITERIA IN EDUCATION SERVICES}

\section{Deming Criteria and its Evaluation}

Based on Deming Prize [14], Deming criteria are categorized under three main categories, which are A, $\mathrm{B}$, and $\mathrm{C}$. The "A category" describes the clear objectives defined by the top management, which reflects into management philosophy, industrial scale, and environment. Moreover, the company needs to establish a proactive customer-oriented business objective and strategy based on organization social responsibility. Besides, top management must exhibit leadership in the formulation of business objective and strategy. The "B category" explains how TQM is suitably implemented and utilized for the realization of business objective and strategy mentioned under the " $\mathrm{A}$ category". The "C category" shows the results achieved through processes in the "B category", which explains the effects towards the organization, along with the achievement of the business objectives and strategies of the "A category," including the outstanding TQM activities in the organization.

Each category is designed with specific evaluation points to be achieved by the organization if they have an interest in participating in the Deming Prize award. Total evaluation points of the "A category" is 100 points, and the same goes for the " $\mathrm{C}$ category". The " $\mathrm{A}$ category" has two criteria; $\mathrm{A} 1$ and $\mathrm{A} 2$, whereas the "C 
category" is separated into the $\mathrm{C} 1$ and $\mathrm{C} 2$, as shown in Fig 3. On the other hand, the "B category" is classified from B1 to B7 in Table 1. The total evaluation point for the "B category" is 100 points. However, the distribution of evaluation points is much more detail as it involved multiple processes to ensure the success of TQM. It is shown in Table 1at the left column.

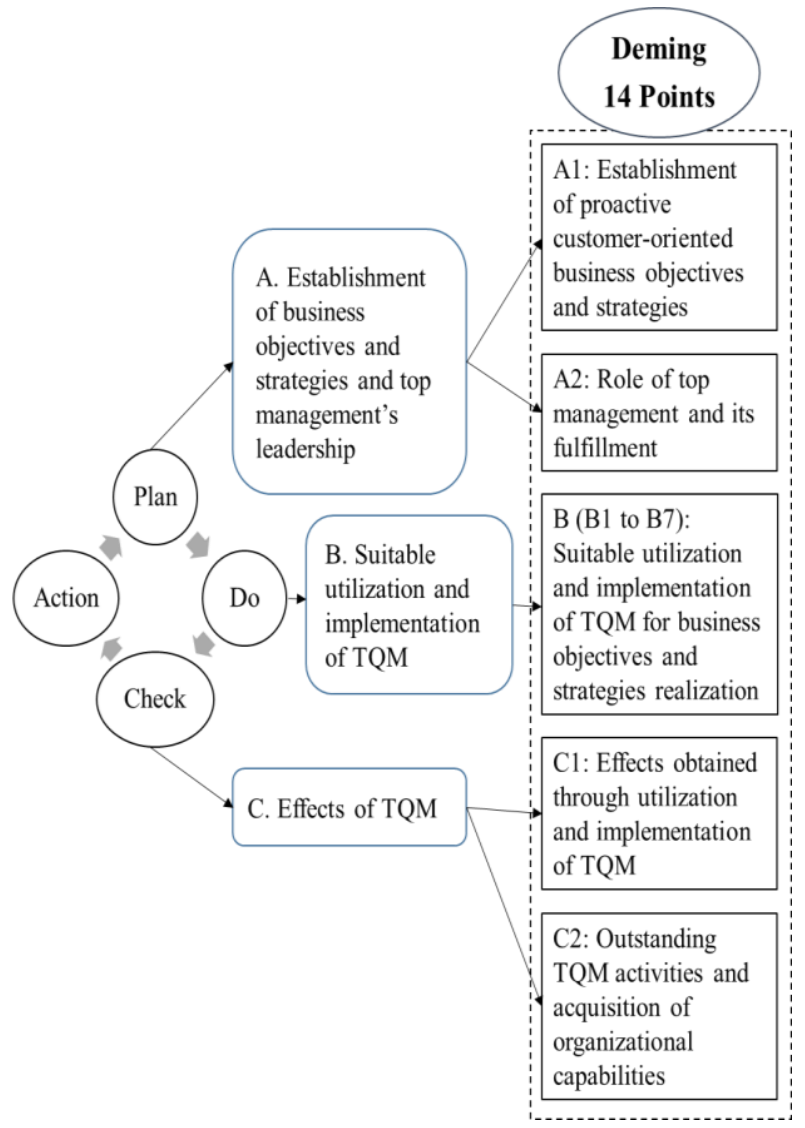

Fig. 3: Overview of Deming Criteria based on the philosophy of Deming 14 Points and PDCA Cycle

In order to build the conceptual framework, it is desired to comprehend the whole TQM implementation process mentioned in Deming criteria. In this study, it is interpreted based on Deming 14 Points and PDCA Cycle, as suggested in Fig. 3. It shows how each element in Deming 14 points links to Deming criteria, and the philosophy is interpreted to elements in the A, B, and C categories. The process of implementation follows the PDCA Cycle, and it will be repeated and continuously improve to specific standards decided by the guidelines. If the organization is a manufacturing entity, the Deming criteria for the company are in the manufacturing-based, and the company will have a unique way to implement the
TQM in their ways. If the education services use the Deming criteria in adopting TQM processes, the Deming criteria shall be made specific to education services and appropriate for the institutions' operation.

Table 1: Deming Criteria for "B category" with its evaluation points

\begin{tabular}{c|l}
\hline $\begin{array}{c}\text { Criteria with } \\
\text { evaluation } \\
\text { points }\end{array}$ & \multicolumn{1}{|c}{ Definition in Deming criteria } \\
\hline $\begin{array}{c}\text { B1: } \\
\text { 15 points }\end{array}$ & $\begin{array}{l}\text { Organizational deployment of } \\
\text { business objectives and strategies. }\end{array}$ \\
\hline B2: & $\begin{array}{l}\text { New value creation based on } \\
\text { customer and social needs' } \\
\text { understanding and business model/ } \\
\text { technology innovations. }\end{array}$ \\
\hline points & $\begin{array}{l}\text { Products and services and work } \\
\text { processes, quality management, } \\
\text { and improvement. } \\
\text { a. Daily work management } \\
\text { b. Continuous improvement }\end{array}$ \\
\hline B4: & $\begin{array}{l}\text { Establishment and operation of } \\
\text { cross-functional management. }\end{array}$ \\
\hline B5: & $\begin{array}{l}\text { Collecting and analyzing the } \\
\text { information from customers, and } \\
\text { accumulation of knowledge, } \\
\text { including its utilization. }\end{array}$ \\
\hline 15 points \\
\hline B6: & $\begin{array}{l}\text { Development and utilization of } \\
\text { human resources } \\
\text { organizational capability. }\end{array}$ \\
\hline 15 points & $\begin{array}{l}\text { Initiatives for social responsibility } \\
\text { in the organization. }\end{array}$ \\
\hline points
\end{tabular}

In Fig. 3, the Deming criteria in the A, B, and C category are general definitions for all sectors; in manufacturing and services. Each criterion has its target result that needs to be achieved by the organization to ensure the success of TQM implementation. By understanding the target for each criterion stated in the Deming Prize [14], the general target result is mapped into education services, and the education services target result is created. This target is to suit the environment from the viewpoint of education milieus. It can be referred at Table 2. As for the B1 (policy management) and B3a (daily work management), these criteria are one of the essential processes in TQM. Sachdev and Agrawal stated that policy management and daily management are the 
vehicles in focusing on strategic improvement and sustenance of an organization [27].

Table 2: Each Deming criteria's target result after mapping into education services

\begin{tabular}{|c|c|}
\hline Criteria & Target result \\
\hline A1 & $\begin{array}{l}\text { The school objectives and strategies are } \\
\text { established based on customer/society } \\
\text { oriented by the clear management belief. } \\
\text { In this context, the customers' definition } \\
\text { of education must be clearly defined; for } \\
\text { example, students, parents, society, etc. } \\
\text { Moreover, the objectives and strategies } \\
\text { related to customers shall be sufficient as } \\
\text { the input of the process and further } \\
\text { improvement. Also, the objectives and } \\
\text { strategy have well-defined for next term. }\end{array}$ \\
\hline $\mathrm{A} 2$ & $\begin{array}{l}\text { Top management exhibits leadership in } \\
\text { the formulation of customers-based } \\
\text { business objective and strategy, } \\
\text { including in the TQM implementation in } \\
\text { the education context. The top } \\
\text { management has a concern about } \\
\text { business objective, strategy, and } \\
\text { environmental change also shall } \\
\text { understand the importance of the } \\
\text { enhancement of organizational } \\
\text { capabilities in their organization. Also, } \\
\text { they show enthusiasm towards TQM to } \\
\text { achieve the business objectives. }\end{array}$ \\
\hline B1 & $\begin{array}{l}\text { Establishment of policy management } \\
\text { based on all significant school } \\
\text { objectives. Business objectives and } \\
\text { strategies are deployed throughout the } \\
\text { school levels and implemented in such a } \\
\text { way based on the involvement of total } \\
\text { employees in education services, and } \\
\text { close cooperation with all levels and } \\
\text { related organizations. } \\
\text { *This is an importantprocess to support } \\
\text { the business objectives and its } \\
\text { operation. }\end{array}$ \\
\hline
\end{tabular}

\begin{tabular}{|c|c|}
\hline B2 & $\begin{array}{l}\text { Development of new educational } \\
\text { services and innovation of work } \\
\text { processes are being carried out } \\
\text { effectively, aiming for the creation of the } \\
\text { new educational value based on the } \\
\text { understanding of the customers' needs. It } \\
\text { includes the continuous improvement of } \\
\text { the new educational service. }\end{array}$ \\
\hline B3a & $\begin{array}{l}\text { Daily work management process related } \\
\text { to education services' is established. The } \\
\text { related process in education, especially } \\
\text { in teaching and learning process needs to } \\
\text { be clearly defined. Problems in } \\
\text { significant operations have been } \\
\text { stabilized throughout the process, with } \\
\text { standardization and proper education or } \\
\text { training to employees. } \\
\text { *This is an importantprocess to support } \\
\text { the business objectives and its } \\
\text { operation. }\end{array}$ \\
\hline B3b & $\begin{array}{l}\text { Continuous improvements in the quality } \\
\text { of education services and work processes } \\
\text { are being carried out in a planned manner } \\
\text { continuously. The customer complaints } \\
\text { and next-processes are decreasing, or are } \\
\text { being maintained at an extremely low } \\
\text { level. Whereas the customer satisfaction } \\
\text { level has improved or is being } \\
\text { maintained at an extremely high level. } \\
\text { Known as "kaizen" in the Japanese term. }\end{array}$ \\
\hline B4 & $\begin{array}{l}\text { Cross-functional management systems } \\
\text { (such as education quality, etc.) } \\
\text { necessary for the organization are being } \\
\text { established. The education quality } \\
\text { assurance system is developed and } \\
\text { operated suitably across the supply chain } \\
\text { headed to society. }\end{array}$ \\
\hline B5 & $\begin{array}{l}\text { Collection of customer needs and } \\
\text { analysis of information is being carried } \\
\text { out in an organized manner. Also, such } \\
\text { information is useful in the creation of } \\
\text { new educational values, management } \\
\text { and improvement of services, and } \\
\text { operational quality. }\end{array}$ \\
\hline
\end{tabular}


Nursuhana Alauddin / Journal of Engineering and Science Research, 3(5) 2019, Pages: 12-20

\begin{tabular}{c|l}
\hline \multirow{3}{*}{ B6 } & $\begin{array}{l}\text { Human resource management is } \\
\text { available and practised. The process is } \\
\text { well-established and effective, being } \\
\text { carried out in a planned manner, and it is } \\
\text { useful to realize the better education. }\end{array}$ \\
\hline \multirow{5}{*}{ B7 } & $\begin{array}{l}\text { Aware of the role in society and the } \\
\text { school has established the process to } \\
\text { understand social responsibility and } \\
\text { actions. Also, adopting initiatives } \\
\text { proactively according to management } \\
\text { philosophy and as the entity of the } \\
\text { educational service industry. }\end{array}$ \\
\hline \multirow{5}{*}{ C1 } & $\begin{array}{l}\text { Education organization has obtained } \\
\text { significant effects on school objectives } \\
\text { and strategies through suitable utilization } \\
\text { andimplementation of TQM. }\end{array}$ \\
\hline C2 & $\begin{array}{l}\text { Education organization has obtained } \\
\text { significant effects on school objectives } \\
\text { and strategies based on multiple } \\
\text { outstanding TQM activities. The } \\
\text { organization has acquired organizational } \\
\text { capabilities necessary for its future } \\
\text { sustainable growth. }\end{array}$ \\
\hline
\end{tabular}

Based on each target result, essential keywords are identified to design the conceptual framework. Every criterion has at least one crucial element to be achieved, and the meaning should be explored based on the education context to create a comprehensive conceptual framework.

\section{Deming Prize Award Categories and its Evaluation Points}

In total, the Deming Prize has four categories; two categories are for organizations, and two categories are specified for individual achievements. The "Deming Prize for Individuals" is given to those who made the outstanding contributions to the TQM study or in the TQM dissemination. For "Deming Distinguished Service Award for Dissemination and Promotion (Overseas)", the recognition is given to individuals who made outstanding contributions in TQM dissemination and promotion. The evaluation will be carried out every three to five years.

On the other hand, for organizations participating in the Deming Prize, it is divided into two categories, and each category has different minimum achievement points for the evaluation. Deming Prize and Deming
Grand Prize category require participants to obtain more than 70 points and 75 points for all $\mathrm{A}, \mathrm{B}$, and $\mathrm{C}$ categories, respectively. The Deming Prize is awarded to the organization that has implemented TQM suits to their management philosophy, the scale of business and management environment. For Deming Grand Prize is given to the organization that had maintained and also enhanced the TQM level for more than three years period after winning the Deming Prize.

By understanding the target evaluation points, helped to design a more comprehensive conceptual framework with more sub-elements to represent TQM processes to be conducted by the organization.

\section{CONCLUSION AND THE WAY FORWARD}

This study demonstrates the overview of Deming criteria to construct the TQM conceptual framework that suits to education services, in general. It provides the idea of creating a more comprehensive model to implement TQM in education, starting from the business objectives and strategies. Moreover, customer definition is also one of the crucial elements in TQM. Once it is formulated with the school objective and strategy, the other TQM processes are used as tools and philosophy in driving the implementation. After the development of comprehensive TQM conceptual framework, an educational institution will be assessed and evaluated to ensure the implementation of TQM is successful and provides positive effects to the organization. It is targeted for a gradual improvement of TQM progress in the organization and the monitoring is suggested to be conducted in several phases thoroughly.

It may be a long journey for the education services to carry out TQM as there are many obstacles, ambiguous measurement, and unclear assessment process standard. Regardless of the upcoming issues, through the TQM implementation process, there are various betterment activities and fruitful advantages to improve the entire organization. Consideration of timeframe, workforce and monetary need to include in the implementation too. In other words, the close discussion and decision making by the top management is an ultimate kick-off point to design the TQM direction. It is hoped that the education service will experience the effects and automatically improve the operation to the betterment. 
Nursuhana Alauddin / Journal of Engineering and Science Research, 3(5) 2019, Pages: 12-20

\section{ACKNOWLEDGEMENT}

The authors acknowledged the related financial support received from Keio Leading-edge Laboratory of Science and Technology (KLL PhD Program Research Grant).

\section{REFERENCES}

[1] N. Zakuan, S. Muniandy, M. Z. Mat Saman, M. S. Md Ariff, S. Sulaiman, and R. Abd Jalil, "Critical success factors of total quality management implementation in higher education institution: A review," Int. J. Acad. Res. Bus. Soc. Sci., vol. 2, no. 12, pp. 19-32, 2012.

[2] B. G. Dale, Managing Quality (Fourth Edition), 4th Ed. Oxford: Blackwell Publishing, 2003.

[3] W. E. Deming, Out of the crisis. Cambridge, Mass.: Massachusetts Institute of Technology, Center for Advanced Engineering Study, 1986.

[4] J. M. Juran and A. B. Godfrey, Juran's Quality Handbook, 5th Ed. New York: McGraw Hill, 1998.

[5] A. V. Feigenbaum, Total Quality Control_Third Edition, 3rd Editio. New York: McGraw Hill, 1983.

[6] Philip B. Crosby, Quality Without Tears: The Art of Hassle-Free Management. New York: McGraw Hill, 1984.

[7] Union of Japanese Scientists and Engineers (JUSE), "TQM • Quality Management (Transl.)," 2015. [Online]. Available: http://www.juse.or.jp/tqm/quality/. [Accessed: 16-Jul-2019].

[8] S. Yamada, TQM Quality Management Introduction (Transl.). Tokyo, Japan: Nikkei Bunko, 2012.

[9] ISO, "ISO 9001:2015 Quality Management Systems," International Organization of Standardization, 2015. [Online]. Available: https://www.iso.org/obp/ui/\#iso:std:iso:9001:e d-5:v1:en. [Accessed: 12-Jul-2019].

[10] F. Talib and Z. Rahman, "Total quality management practices in manufacturing and service industries: a comparative study," Int. J. Adv. Oper. Manag., vol. 4, no. 3, pp. 155-176, 2012.

[11] F. Talib, Z. Rahman, and M. N. Qureshi, "Total quality management in service sector: A literature review," Int. J. Bus. Innov. Res., vol. 6, no. 3, pp. 259-301, 2012.

[12] D. S. Tachiki, "TQM in the public sector," 2008. [Online]. Available: https://www.researchgate.net/publication/2733 82172. [Accessed: 10-Aug-2019].

[13] N. Alauddin and S. Yamada, "Application of Deming Criteria to Implement TQM in School Education," in The 49th Annual Conference Research, 2019, pp. 19-22.

[14] Union of Japanese Scientists and Engineers (JUSE), "Introduction of the Deming Prize," Union of Japanese Scientists and Engineers, 2015. [Online]. Available:

http://www.juse.or.jp/upload/files/DP_Introduc tion_of_the_Deming_Prize2019.pdf. [Accessed: 28-Jun-2019].

[15] K. Hasan, M. S. Islam, A. T. Shams, and H. Gupta, "Total Quality Management (TQM): Implementation in Primary Education System of Bangladesh," Int. J. Res. Ind. Eng., vol. 7, no. 3, pp. 370-380, 2018.

[16] Y. Kamarul Bahari and S. Norsamsinar, "The Development Of Measurement Instruments For Total Quality Management Practices In Higher Education Institution," Adv. Soc. Sci. Educ. Humanit. Res., vol. 239, pp. 114-118, 2018.

[17] N. Ravindran and R. Karpaga Kamaravel, "Total Quality Management in Education: Prospects, Issues and Challenges," Shanlax Int. J. Educ., vol. 4, no. 2, pp. 58-65, 2016.

[18] L. Porter and S. Tanner, Assessing Business Excellence, 2nd Ed. London: Elsevier Butterworth-Heinemann, 2004.

[19] Union of Japanese Scientists and Engineers (JUSE), "The Application Guide for The Deming Prize For Companies and Organizations Overseas," The Deming Prize Committee Union of Japanese Scientists and Engineers, 2018. [Online]. Available: https://www.juse.or.jp/upload/files/Deming_pri ze_EN/download/Application_Guide.pdf. [Accessed: 26-Jun-2019].

[20] K. Koura, "TQM Model of ElementsDeployment Table Developed from Quality Award and its Application," Tsukuba University, 2004.

[21] M. Izadi, A. E. Kashef, and R. W. Stadt, "Quality in Higher Education: Lessons Learned from the Baldrige Award, Deming Prize, and ISO 9000 Registration," J. Ind. Teach. Educ., vol. 33, no. 2, pp. 60-76, 1996.

[22] F. C. Lunenburg, "Total Quality Management Applied to Schools," Schooling, vol. 1, no. 1, pp. 1-6, 2010.

[23] A. W. Hughey, "Application of the Deming Philosophy to Higher Education," Ind. High. Educ., vol. 14, no. 1, pp. 40-44, 2000.

[24] M. S. Farooq, M. S. Akhtar, S. Z. Ullah, and R. A. Memon, "Application of Total Quality Management in Education," J. Qual. Technol. 
Manag., vol. 3, no. 2, pp. 87-97, 2007.

[25] J. Nawelwa, C. Sichinsambwe, and B. G.

Mwanza, "An analysis of total quality

management (TQM) practices in Zambian

secondary schools," TQM J., vol. 27, no. 6, pp.

716-731, 2015.

[26] P. M. Patel and V. A. Deshpande, "Application Of Plan-Do-Check-Act Cycle For Quality And Productivity Improvement - A Review," Int. J. Res. Appl. Sci. Eng. Technol., vol. 5, no. I, pp. 197-201, 2017.

[27] A. Sachdev and J. Agrawal, "Application of Policy Deployment and Daily Management in service sector," Int. J. Qual. Innov., vol. 3, no. 8, pp. 1-17, 2017. 